\title{
Jurist-Diction
}

Volume 3 No. 5, September 2020

\section{Pertanggungjawaban Pidana Pelaku Pinjaman Online yang Berimplikasi Tindak Pidana}

\author{
Anggraini Dila Pitaloka \\ anggrainipitaloka5@gmail.com \\ Universitas Airlangga
}

How to cite:

Anggraini Dila Pitaloka,

'Pertanggungjawaban Pidana Pelaku Pinjaman Online yang Berimplikasi Tindak Pidana' (2020) Vol. 3 No. 5 JuristDiction.

Histori artikel:

Submit 17 Juli 2020;

Diterima 14 Agustus 2020;

Diterbitkan 1 September 2020.

DOI:

10.20473/jd.v3i5.21968

\begin{abstract}
Abstrak
Internet merupakan media elektronik yang memiliki banyak manfaat dalam berbagai bidang, terutama dalam bidang ekonomi. Perkembangan dalam bidang teknologi dan komunikasi menjadi salah satu penyebab dan adanya perkembangan pesat dalam bidang ekonomi global. Di era teknologi keuangan saat ini, muncul model bisnis baru yang berkembang cukup pesat di Indonesia, yaitu peer to peer (P2P) lending atau layanan pinjaman berbasis teknologi informasi (online). Pinjaman online merupakan salah saktu bukti bahwa masyarakat global saling terhubung dalam memanfaatkan teknologi. Dengan aplikasi pinjaman online ini, semua orang dapat mengajukan pinjaman kapanpun dan dimanapun selama dia memiliki smartphone dan komputer yang digunakan terkoneksi dengan internet. Namun seiring perkembangan teknologi justru kemajuan teknologi banyak di salah gunakan. Sehingga, banyak menimbulkan resiko dan munculnya tindak pidana, contohnya saja tindak pidana penipuan, pemerasan, pengancaman terkait dengan informasi dan teknologi. Penipuan yang dimaksud adalah rangkaian kebohongan mengenai suatu objek tertentu yang tidak sesuai dengan objek aslinya. Pemerasan merupakan setiap orang dengan maksud untuk menguntungkan dirinya atau orang lain dengan melanggar hukum. Memaksa orang dengan kekerasan atau ancaman mengutang atau menghapus piutang. Dalam pidana, segala pihak dapat dikenakan pidana termasuk dalam hal membantu tindak pidana.

Kata Kunci: Pertanggungjawaban Pidana; Penipuan; Pemerasan; Pengancaman; Pinjaman Online.
\end{abstract}

\section{Pendahuluan}

Saat ini modus kejahatan semakin bervariasi dengan terdukungnya perkembangan teknologi, sehingga teknologi tersebut juga digunakan tipu daya muslihat sebagai modus kejahatan yang berakibat kejahatan dari teknologi tersebut. Salah satu fitur yang berkembang adalah Intranet. Secara historis, perkembangan munculnya internet bermula dari telematika. Telematika tersebut ditemukan pada tahun 1976. Dalam bahasa Perancis istilah telematika berasal dari kata telematique yang menjelaskan terjadinya penggabungan sistem 
jaringan komunikasi dan teknologi informasi ${ }^{1}$ sedangkan teknologi informasi hanya menjelaskan mengenai perkembangan perangkat yang ada pada pengolah informasi saja. Media elektronik dan teknologi informasi ini bisa dijadikan sebagai pelopor yang bisa meyatukan seluruh sistem dunia baik dalam aspek ekonomi, keuangan, sosial dan budaya, sehingga perkembangan tersebut bisa membantu manusia dalam kehidupan sehari-hari.

Berkembangnya teknologi saat ini menyebabkan munculnya layanan keuangan dengan teknologi informasi yang biasanya disebut dengan Financial Technology atau fintech. Melalui fintech transaksi menjadi lebih cepat dalam melakukan pembayaran tanpa harus bertatap muka. Kemajuan teknologi pada saat ini, dapat menaikkan perkembangan di segala sektor kehidupan di masyarakat. Sehingga memudahkannya untuk melakukan segala hal yang ingin dilakukan, serta membawa kehidupan masyarakat yang awalnya bercorak tradisional menjadi lebih modern atau bisa disebut juga dengan istilah modernisasi. ${ }^{2}$ Perkembangan fintech ini memiliki berbagai macam sektor mulai dari startup pembayaran, peminjaman (lending), perencanaan keuangan (personal finance), investasi ritel pembiayaan (crowdfunding), remintasi, riset keuangan dan lain-lain.

Kemajuan teknologi saat ini, seharusnya bisa dimanfaatkan dengan baik agar dapat mengubah perilaku dan dapat membantu menyelesaikan setiap permasalahan yang sedang dihadapi. Banyak dari generasi muda yang memanfaatan internet dalam kehidupan sehari-hari untuk merasakan kelebihan fintech yang dapat digunakan lebih mudah dan praktis. Alasan kedua fintech berkembang lebih pesat karena dengan keadaan teknologi yang semakin cepat ini, dapat membantu pekerjaan bagi para pelaku usaha fintech untuk menyelesaikan pekerjaanya dengan sangat cepat dan mudah. Dengan adanya fintech ini, masyarakat dapat memenuhi kebutuhan di bidang keuangan dengan sangat mudah dan praktis. Perekonomian di Indonesia juga semakin membaik setelah adanya fintech ini. OJK (Otoritas Jasa Keuangan) juga turut mengawasi jalannya bisnis tersebut agar tidak ada konsumen

\footnotetext{
Edmon Makarim, Kompilasi Hukum Telematika (Raja Grafindo Persada 2004).[3].

2 A.K. Mihardja, Polemik Kebudayaan (Balai Pustaka 1998).[19].
} 
yang merasa dirugikan dan fintech tetap memberikan layanan yang sesuai dengan aturan yang ada. Perkembangan teknologi saat ini, telah banyak mengubah sistim interaksi masyarakat, yaitu interaksi bisnis, ekonomi, sosial dan budaya. Kemajuan teknologi komunikasi khususnya di bidang komunikasi dalam dunia online sudah digunakan untuk bertransaksi, jual beli online bahkan sampai timbulnya munculnya pinjaman online.

Kecanggihan teknologi saat ini telah memberikan banyak kemudahan, terutama dalam membantu pekerjaan manusia dalam berbagai bidang. Sehingga munculnya kejahatan-kejahatan baru, yaitu dengan menggunakan komputer sebagai alat modus operandinya. ${ }^{3}$ Salah satu contoh kasus yang terkait adalah pinjaman online, kasus tersebut banyak diperbincangkan karena kasus tersebut memakan banyak nyawa dan banyak yang mengeluhkan ke dalam tindak pidana penipuan. Sesuai dengan namanya pinjaman online adalah layanan kredit pinjaman yang menggunakan teknologi informasi, pinjaman ini sudah mulai berkembang sejak pertengahan tahun 2014. Banyak orang yang mulai menggunakan pinjaman online karena di era sekarang kebutuhan tidak lagi hanya sebatas bertemu melainkan hanya menggunakan internet, semua bisa cepat dan lebih mudah. Bahkan masyarakat tak perlu lagi mendatangi bank dan mengajukan permohonan langsung untuk mendapatkan pinjaman tersebut. Dengan kemudahan tersebut banyak masyarakat yang memilih pinjaman online dibandingkan harus pinjam di bank. Dari kemudahan tersebut timbullah celah tindak pidana.

Banyaknya laporan terkait kasus tersebut dikarenakan banyak orang yang merasa tertipu dengan pinjaman online. Sedangkan belum dipastikan dalam kasus pinjaman online kreditur yang menjadi korban, hal tersebut terjadi karena saat ini banyak dari pihak debitur (nasabah) yang lalai dalam melakukan pembayaran sesuai dengan kesepakatan diawal, Jika debitur melakukan hal tersebut maka debitur telah melakukan wanprestasi, karena telah mengingkari perjanjian yang telah disepakati. Perbuatan si debitur merupakan perbuatan yang tidak menepati janji, dikarenakan

3 Maskun, Kejahatan Siber (Cyber Crime) (Prenada Media Group 2013).[17]. 
tidak membayar hutang terhadap si kreditur yang membuat kreditur mengalami kerugian. ${ }^{4}$ Hubungan yang timbul antara pihak kreditur (pinjaman online) dan debitur (nasabah) merupakan konsep hukum privat yang lebih dikenal dengan sebutan wanprestasi. Dampak dari wanprestasi tersebut membuat si kreditur melakukan hal-hal yang membuat si debitur melakukan pengancaman melalui SMS, didatangi debt collector di rumah, hingga mencemarkan nama baik si debitur. Dampak tersebut menimbulkan yang pada awalnya hanya terjadi wanprestasi menjadi tindak pidana dalam kasus pinjaman online. Karena tidak selalu penyelesaian persoalan tersebut selalu berhubungan dengan penyelesaian hukum privat, tetapi bisa juga melalui instrument hukum pidana. Tidak hanya keuntungan pinjaman online juga memiliki kekurangan, yaitu:a. Memiliki suku bunga yang tinggi; b. Ada batasan dalam meminjam uang; c. Cara penagihan hutang yang kurang baik.

Dampak kelemahan tersebut menimbulkan si debitur harus tutup lubang gali lubang dalam melakukan pembayaran. Hal tersebut dilakukan karena para korban tidak mampu membayar dengan bunga yang semakin tinggi di setiap harinya. Selain itu juga banyak korban yang selalu dikejar-kejar oleh debt collector sehingga mereka merasa terancam dan takut akan ancaman-ancaman para debt collector tersebut. Akibat lain yang ditimbulkan dari pinjaman online adalah:a. Menjual ginjal untuk melunasi hutangnya; b. Mengundurkan diri dari pekerjaan; c. Dipecat dari pekerjaan; c. Timbulnya rasa malu; d.Bunuh diri .

\section{Karakteristik Pinjam Online}

Pinjaman online ini diawali oleh perusahaan Financial Technology atau lebih dikenal dengan sebutan fintech. Sehingga, mulai timbullah banyak lembaga keuangan termasuk perbankan yang mencoba mengintegrasikan sistem operasional dengan teknologi informasi yang berkembang melalui smartphone atau komputer yang terkoneksi dengan internet. Maka dari itulah layanan kredit pinjaman online bank mulai tumbuh subur di Indonesia.

4 Moeljatno, Asas-Asas Hukum Pidana (Rineka Cipta 2002).[3]. 
Pinjaman online merupakan layanan produk berupa kredit pinjaman yang menggunakan sarana teknologi informasi. Pelayanan yang diberikan mulai dari proses pengajuan dana pinjaman, acceptance, hingga pencairan dana pinjaman online melalui email, sms, maupun telefon. Dapat dilihat dari penjelasan diatas, banyak kreditur dan debitur sama sekali tidak bertatap muka secara langsung.

Berbeda jika dibandingkan dengan pinjaman secara konvensional adalah sebagai berikut:

a. Pemilik dana mendapatkan keuntungan dari bunga yang ditetapkan sebagai tambahan kepada nasabah;

b. Bank konvensional hanya mengejar keuntungan semata;

c. Hubungan yang dijalin nasabah dengan orang yang meminjamkan dana hanyalah sebatas nasabah dan kreditur dan tidak memiliki ikatan emosional;

d. Jika terdapat perselisihan atau sengketa yang melibatkan bank konvensional maka jalur yang ditempuh adalah jalur hukum dengan pengadilan negeri sebagai pihak penyelesaikan sengketa.

Di Indonesia, yang berwenang mengatur peraturan terhadap perusahaan pinjaman online adalah OJK atau biasa disebut dengan Otoritas Jasa Keuangan. OJK merupakan lembaga Negara yang dibentuk berdasarkan Undang-Undang Nomor 21 Tahun 2011 yang berfungsi menyelenggarakan sistem pengaturan dan pengawasan yang mengatur keseluruhan kegiatan di dalam sektor jasa keuangan baik di dalam sektor perbankan, pasar modal, dan sektor jasa keuangan non-bank contohnya Asuransi, Dana Pensiun, Lembaga Pembiayaan, dan Lembaga Jasa Keuangan lainnya. Di dalam melakukan pengawasannya, OJK memberikan perlindungan dan edukasi bagi konsumen yang dapat mengarahkan untuk mencapai dua tujuan utama.

Dari ke 113 daftar tersebut dipilih 5 (lima) untuk mewakili perusahaan pinjaman online per 31 Mei 2019 yang telah resmi terdaftar, yaitu:

1. Danamas, nama perusahaanya adalah PT Pasar Dana Pinjaman;

2. Koinworks, nama perusahaannya adalah PT Lunaria Annua Teknologi;

3. Amartha, nama perusahaannya adalah PT Amartha Mikro Fintek;

4. Investree,nama perusahaannya adalah PT Investree Radhika Jaya;

5. Danacepat, nama perusahaannya adalah PT Pendanaan Teknologi Nusa.

OJK telah melakukan berbagai upaya untuk menutup berbagai ratusan perusahan pinjaman online yang tak berizin (ilegal). Berikut adalah beberapa daftar pinjaman online yang beroperasi secara ilegal di Indonesia, yaitu: 
1. AyoRupiah (PT Inspirasi Global Indonesia);

2. Bee Cash (Wangjunhua);

3. Bos Tunai (PT Waves Teknologi Indonesia);

4. Cash Loan 2 Minutes (Loan Instant \& fast);

5. Go Go Uang (PT Indo Guna Sejahtera).

\section{Perbuatan Yang Dilarang Dalam Pinjaman Online}

Sebelum memasuki perbuatan yang dilarang dalam pinjaman online, terlebih dahulu kita harus mengetahui apa itu perbuatan pidana atau tindak pidana. Di dalam Undang-undang Hukum Pidana (KUHP) tindak pidana lebih dikenal dengan istilah "Strafbaar Feit". Dalam "Strafbaar Feit" ini, Moeljatno menafsirkan istilah perbuatan pidana sebagai "perbuatan yang dilarang oleh suatu aturan hukum, larangan yang mana disertai ancaman (sanksi) yang berupa pidana tertentu bagi barangsiapa yang melanggar larangan tersebut". ${ }^{5}$ Berdasarkan pendapat tersebut, dapat disimpulkan bahwa pengertian tindak pidana merupakan suatu perbuatan yang melanggar suatu aturan hukum, yang dapat dikenakan sanksi pidana bagi setiap orang yang melanggar aturan tersebut yang ditujukan kepada perbuatan, sedangkan ancaman atau sanksinya dapat ditujukan kepada orang yang melakukan kejahatan tersebut. Selain itu, Bambang Poernomo berpendapat bahwa tindak pidana akan lebih lengkap apabila "Bahwa perbuatan pidana adalah suatu perbuatan yang oleh suatu aturan hukum pidana dilarang dan diancam dengan pidana bagi barang siapa yag melanggar aturan tersebut". ${ }^{6}$ Hukum pidana merupakan bagian dari keseluruhan hukum yang berlaku di suatu negara, yang mengadakan dasar-dasar dan aturan-aturan untuk:

a. Menentukan perbuatan-perbuatan mana yang tidak boleh dilakukan, yang dilarang, dengan disertai ancaman atau sanksi yang berupa pidana tertentu bagi barangsiapa melanggar tersebut.

b. Menentukan kapan dan dalam hal-hal apa kepada mereka yang telah melanggar larangan-larangan itu dapat dikenakan atau dijatuhi pidana sebagaimana yang telah diancamkan.

\footnotetext{
5 Moeljatno, Asas-asas Hukum Pidana (Rinekacipta 2008).[59].

6 Bambang Poernomo, Asas-asas Hukum Pidana (Ghalia Indonesia 1992).[130].
} 
c. Menentukan dengan cara bagaimana pengenaan pidana itu dapat dilaksanakan apabila ada orang yang disangka telah melanggar larangan tersebut. ${ }^{7}$

Dari penjelasan tersebut, maka dapat disimpulkan bahwa perbuatan pidana merupakan perbuatan yang dilarang dalam suatu peraturan perundang-undangan dan memiliki sanksi apabila dilakukan.

Persoalan hukum yang muncul akibat pinjaman online tersebut adalah:

a. Penipuan

Secara umum tindak pidana penipuan masuk di dalam kejahatan terhadap harta kekayaan, sebagaimana diatur dalam Pasal 378 KUHP, yaitu:

"Barangsiapa dengan maksud untuk mnguntungkan diri sendiri atau orang lain secara melawan hukum, dengan memakai nama palsu atau martabat palsu, dengan tipu muslihat, ataupun rangkaian kebohongan, menggerakkan orang lain untuk menyerahkan barang sesuatu kepadanya, atau supaya memberi hutang maupun menghapuskan piutang diancam karena penipuan dengan pidana penjara paling lama empat tahun".

Di dalam ketentuan Pasal 378 KUHP memiliki 2 (dua) unsur pokok, yaitu unsur objektif dan unsur subjektif. Unsur objektif yaitu membujuk atau menggerakkan orang lain dengan alat pembujuk atau penggerak:

1. Memakai nama palsu;

2. Martabat atau keadaan palsu;

3. Rangkaian kata bohong, tipu muslihat;

4. Menyerahkan sesuatu barang;

5. Membuat hutang;

6. Menghapuskan piutang. ${ }^{8}$

Meskipun unsur-unsur dalam Pasal 378 KUHP tersebut terpenuhi seluruhnya, tetapi terdapat unsur dari tindak pidana penipuan online yang tidak terpenuhi dalam pengaturan Pasal 378 KUHP, yaitu tidak terpenuhinya unsur media utama yang digunakan dalam melakukan tindak pidana penipuan online yaitu media elektronik yang belum dikenal dalam KUHP maupun KUHAP, cara-cara penipuan yang berbeda antara penipuan konvensional dengan penipuan online, dan juga terdapat

7 Didik Endro Purwoleksono, Hukum Pidana (Airlangga University Press 2013).[ 3].

8 Yahman, Karakteristik Wanprestasi \& Tindak Pidana Penipuan (PT. Prestasi Prestasi Pustakaraya 2011).[109]. 
keterbatasan dalam KUHP yaitu tidak dapat membebankan pertanggungjawaban pidana pada subyek hukum yang berbentuk badan hukum (korporasi) yang melakukan tindak pidana penipuan online.

Namun, di dalam Pasal 378 KUHP jika dikaitkan dengan kasus pinjaman online saat ini yang menjadi letak penipuannya adalah jika kita meminjam uang sebesar Rp. 1.000.000,- maka yang kita dapatkan di rekening kita adalah Rp.600.000,- perjanjian tersebut tidak disebutkan dengan jelas mengapa pinjaman yang awalnya Rp. 1.000.000,- menjadi Rp. 600.000,- tersebut. Pihak pinjaman tersebut hanya menjelaskan potongan biaya administrasi. Maka yang dimaksud dengan penipuannya adalah pinjaman yang diberikan tidak sesuai dan banyak potongan yang tidak disebutkan secara terperinci.

Kasus tersebut menjelaskan bahwa pihak debitur mengalami kerugian dan telah terjadi unsur penipuan dari pihak kreditur yang tidak sesuai dengan perjanjian semestinya. Delik penipuan ini ditujukan kepada para aplikasi fintech yang dalam memberikan pinjaman kepada nasabah yang tidak sesuai dengan perjanjian di awal/ banyaknya potongan yang tidak dijelaskan kepada para nasabah yang meminjam. Sehingga, para nasabah yang meminjam uang tersebut baru tahu melalui uang yang masuk di nomer rekeningnya.

Para kreditur ketika si debitur tidak megembalikan uang sesuai dengan batas jatuh tempo yang telah disepakati maka akan dikenakan bunga sesuai dengan persetujuan awal.

Dalam melakukan penagihan para kreditur melakukan tindak pidana sebagai berikut:

\section{a. Pemerasan}

Secara umum tindak pidana pemerasan masuk di dalam Bab XXIII tentang pemerasan dan pengancaman, sebagaimana diatur dalam Pasal 368 KUHP, yaitu:

(1) Barangsiapa dengan maksud untuk mneguntungkan diri sendiri atau orang lain secara melawan hukum, memaksa seseorang dengan kekerasan atau ancaman kekerasan untuk memberikan sesuatu barang, yang seluruhnya atau sebagian adalah kepunyaan orang itu atau orang lain, atau supaya membuat utang atau menghapuskan piutang, diancam karena pemerasan, dengan pidana penjara paling lama Sembilan tahun.

(2) Ketentuan Pasal 365 ayat (2), (3), dan (4) berlaku bagi kejahatan ini. 
Bagian unsur delik dalam Pasal tersebut, yaitu:

1. Dengan maksud untuk menguntungkan diri sendiri atau orang lain;

2. Secara melawan hukum;

3. Memaksa seseorang dengan kekerasan atau ancaman kekerasan;

4. Untuk memberikan sesuatu barang, yang seluruhnya atau sebagian adalah kepunyaan orang itu atau orang lain, atau supaya membuat utang atau menghapusnya piutang. ${ }^{9}$

Di dalam delik pemerasan dan penipuan merupakan delik harta benda barang yang diserahkan dalam bentuk barang tidak berwujud, yaitu utang atau penghapus piutang. Kalau dalam delik pencurian, barang yang diambil tidak mungkin berupa penghapusan utang. Penghapusan utang misalnya dengan paksaan, seseorang menandatangani kuitansi tanda lunas, tetapi dia belum membayarnya. ${ }^{10}$

b. Pengancaman

Secara umum tindak pidana pemerasan masuk di dalam Bab XXIII tentang pemerasan dan pengancaman, sebagaimana diatur dalam Pasal 369 KUHP, yaitu:

(1) Barangsiapa dengan maksud untuk menguntungkan diri sendiri atau orang secara melawan hukum, dengan ancaman akan membuka rahasia, memkasa orang supaya memberikan sesuatu barang yang seluruhnya atau sebagian kepunyaan orang itu atau orang lain, atau supaya membuat utang atau menghapuskan piutang, diancam dengan pidana penjara paling lama empat tahun.Kejahatan ini tidak dituntut kecuali atas pengaduan orang yang terkena kejahatan.

Cara pengancaman ini, yaitu akan menista atau akan membuka rahasia kepada orang lain atau para publik yang berhubungan dengan kehidupan pribadi orang yang diancam atau seorang ketiga dalam hubungan dengan orang yang diancam. Perbedaannya adalah bahwa suatu rahasia pada hakikatnya mengenai suatu hal yang benar terjadi, tetapi penistaan yang memberitakan benar atau tidaknya yang disembunyikan karena hal tertentu, sedangkan yang cemarkan adalah nama dan kehormatan dari orang yang diancam atau orang ke tiga, yang memiliki hubungan keluarga atau persahabatan dengan orang yang diancam. ${ }^{11}$

\footnotetext{
9 Andi Hamzah, Delik-Delik Tertentu (Speciale Delicten) Di Dalam KUHP (Sinar Grafika 2009).

10 ibid.[85].

11 Wirjono Prodjodikoro, Tindak-Tindak Pidana Tertentu Di Indonesia (PT. Refika Aditama 2003).[29].
} 
Jika rahasia yang bersangkutan tidak tidak hanya berkaitan dengan dirinya sendiri namun juga mengenai apa saja yang oleh orang yang diancam dihendaki jangan sampai diketahui oleh banyak orang. Maka hal tersebut berlainan, artinya dari rahasia tersebut dimaksudkan dalam Pasal 322 KUHP, yang mengenai pembukaan rahasia oleh orang yang, karena jabatannya atau pekerjaanya, berwajib menyimpan rahasia itu. ${ }^{12}$

\section{c. Pelanggaran Privasi}

Penyalahgunaan privasi KTP yang terjadi dalam pinjaman online, telah melanggar peraturan perundang-undangan. Pasal 85 Undang-Undang Administrasi Kependudukan, selain itu juga Pasal 17 huruf (h) Undang-Undang Nomor 14 tahun 2008 yang menyatakan bahwa informasi publik yang dikecualikan untuk wajib dibuka, yaitu: riwayat dan kondisi anggota keluarga, riwayat kondisi dan perawatan, pengobatan kesehatan fisik dan psikis seseorang seseorang, kondisi keuangan, aset, pendapatan, dan rekening bank seseorang, hasil-hasil evaluasi sehubungan dengan kapabilitas, intelektualitas, dan rekomendasi kemampuan seseorang, dan/atau catatan yang menyangkut pribadi seseorang yang berkaitan dengan kegiatan satuan pendidikan formal dan satuan pendidikan nonformal.

\section{d. Penghinaan}

Pasal 310 KUHP berbunyi:

(1) Barangsiapa dengan sengaja menyerang kehormatan atau nama baik seseorang dengan menuduhkan sesuatu hal, yang maksudnya terang supaya hal itu diketahui umum, diancam karena pencemaran, dengan pidana penjara paling lama Sembilan bulan atau pidana denda paling banyak empat ribu lima ratus rupiah.

(2) Jika hal itu dilakukan dengan tulisan atau gambaran yang disiarkan, dipertunjukkan atau ditempelkan di muka umum, maka diancam karena pencemaran tertulis dengan pidana paling lama satu tahun empat bulan atau pidana denda paling banyak empat ribu lima ratus rupiah.

(3) Tidak merupakan pencemaran atau pencemaran tertulis jika perbuatan itu jelas dilakukan demi kepentingan umum atau karena terpaksa untuk membela diri. 
Contoh kasus yang dapat diambil dari kasus pinjaman online ini terkait penangkapan empat orang yang menjadi pekerja di PT Vcard Technology Indonesia atau Vloan. Kepala Subdirektorat II Direktorat Tindak Pidana Siber Bareskim Polri Komisaris Besar Polisi Rickynaldo Chairul mengatakan bahwa dalam melakukan penagihan ke-4 Debt collebtor mengakses seluruh data yang terdapat dalam isi HP nasabah tersebut. Karena, ketika para nasabah mendownload aplikasi pinjaman Vloan, maka nasabah akan mengikuti dan menyetujui seluruh aturan yang terdapat dalam aplikasi tersebut agar pinjaman dapat disetujui. Setelah mengakses persyaratan dari Vloan, maka seluruh data yang ada di dalam HP nasabah akan dapat diakses melalui aplikasi”., ujarnya.

\section{Tindak Pidana Penipuan Menurut Undang-Undang Nomor 11 Tahun 2008 Tentang Informasi dan Informasi dan Transaksi Elektronik}

Pada dasarnya UU ITE mengatur secara khusus tentang pengancaman dan pemerasan, yaitu dapat dilihat dalam Pasal 29 UU ITE yang mengatur perbuatan berupa ancaman kekerasan atau menakut-nakuti secara pribadi dengan mengirimkan informasi dan/atau dokumen elektronik. Berbeda jika dibandingkan dengan ketentuan Pasal 27 ayat (4) khusus pengancaman. ${ }^{13}$ Pengancaman Pasal 27 ayat (4) berisikan ancaman yang berupa pencemaran nama baik dengan lisan atau tulisan atau ancaman membuka rahasia dengan maksud untuk menguntungkan diri sendiri atau orang lain, memaksa orang lain memberikan barang sesuatu, memberi utang atau menghapuskan piutang, sementara di dalam Pasal 29 menjelaskan tentang ancaman kekerasan atau menakut-nakuti secara pribadi. ${ }^{14}$

Ketentuan ini mirip dengan cyberstalking yang kasusnya berada di Amerika Serikat, Kanada, Inggris dan negara lainnya, contohnya tindakan pelecehan atau ancaman atau tindakan lainnya yang dapat menimbulkan rasa takut yang dilakukan baik dengan perkataan atau tindakan tertentu yang menggunakan teknologi informasi dan komunikasi, contohnya dalam bentuk unsolicited hate mail, obscene

\footnotetext{
${ }^{13}$ Sigid Suseno, Yurisdiksi Tindak Pidana SIBER (PT Refika Aditama 2012).[173].

14 ibid.
} 
or threatening email, 'mail bombs, dan lain-lain. ${ }^{15}$

Dalam Pasal 29 UU ITE ini mempunyai peraturan yang sangat penting karena media internet atau media elektronik lainnya saat ini digunakan bagi para pelaku kejahatan untuk melakukan ancaman baik seksual atau keamanan terhadap orang lain. Sehingga, menimbulkan timbulnya rasa takut dalam diri para korban, sedangkan ketentuan terhadap pengancaman tidak mungkin diterapkan untuk perbuatan tersebut. ${ }^{16}$

Perbuatan yang diatur di dalam Pasal 29 UU ITE mensyaratkan dilakukan "dengan sengaja" dan "tanpa hak" dalam ketentuan tersebut tidak termausk perbuatan yang dilakukan dengan lalai (culpa) atau dilakukan berdasarkan kewenangan atau hukum yang berlaku. ${ }^{17}$ Sanksi pidana atas pelanggaran ketentuan Pasal 29 berdasarkan ketentuan Pasal 45 ayat (3) UU ITE adalah pidana penjara 12 tahun dan/atau denda 2 Milyar rupiah.

\section{Konsep Pertanggungjawaban Pidana}

Pertanggungjawaban pidana merupakan aturan mengenai bagaimana memperlakukan siapa saja yang melanggar norma-norma, moral, agama, dan hukum yang ada di dalam masyarakat tersebut. ${ }^{18}$ Dalam konsep pertanggungjawaban pidana pada dasarnya kembali kepada pemahaman pemidanaan terhadap pelaku tindak pidana. Menurut Hart, konsep tindak pidana dan pertanggungjawaban pidana sangatlah berbeda, hal tersebut dapat dilihat dari adanya struktur aturan yang berbeda. Hart mengemukakan bahwa "primary laws setting standarts for behavior and secondary laws specifying what officials must or may do when they are broken". Maka dapat dilihat bahwa, dipisahkannya antara aturan hukum primer yang berisi aturan tentang berperilaku, dan aturan hukum sekunder yang menentukan apa yang harus atau mungkin dilakukan bagi siapa yang melanggar aturan tersebut. Pertanggungan

\footnotetext{
15 ibid.

16 ibid.[174].

17 ibid.

${ }^{18}$ Chairul Huda, Dari Tiada Pidana Tanpa Kesalahan'Menuju Kepada “Tiada Pertanggungjawaban Pidana Tanpa Kesalahan ( Prenada Media 2006).[19].
} 
jawab itu diartikan dengan adanya hubungan antara kenyataan-kenyataan yang telah menjadi syarat dan akibat hukum apa saja yang telah disyaratkan. ${ }^{19}$ Seseorang dapat dimintakan pertanggungjawaban pidana, jika orang tersebut telah melakukan tindak pidana. Moeljatno mengatakan, "orang tidak mungkin dipertanggungjawabkan (dijatuhi pidana) kalau dia tidak melakukan perbuatan pidana". ${ }^{20}$ Dengan demikian, pertanggungjawaban pidana tersebut tergantung dengan tindak pidana apa yang telah dilakukannya. Seseorang dapat dikenakan pertanggungjawaban pidana, jika orang tersebut telah melakukan tindak pidana.

Menurut Kitab Undang-Undang Hukum Pidana tidak mengatur pengertian tentang pertanggungjawaban pidana, namun di dalamnya memiliki aturan yang berhubungan tentang bertanggungjawab, yaitu dalam Pasal 44 ayat (1) KUHP, yang berbunyi "Barangsiapa melakukan perbuatan yang tidak dapat dipertanggungjawabkan padanya, disebabkan karena jiwanya cacat dalam tumbuhnya (gebrekkige ontwikkeling) atau terganggunya karena penyakit (ziekelijke storing), tidak dipidana.”

Berdasarkan Pasal 44 ayat (1) tersebut, moeljatno menyimpulkan bahwa untuk adanya kemampuan bertanggung jawab harus ada:

1. Kemampuan untuk membeda-bedakan antara perbuatan yang baik dan yang buruk, yang sesuai dengan aturan hukum dan yang melawan hukum;

2. Kemampuan untuk menentukan kehendaknya menurut keinsyafan tentang baik dan buruknya perbuatan. ${ }^{21}$

Dalam kemampuan bertanggung jawab, dapat dilihat dalam faktor akal, yaitu apakah pelaku tersebut membedakan antara perbuatan yang diperbolehkan dan yang tidak. Selain itu juga dilihat dari faktor perasaan atau kehendak si pelaku, yaitu apakah pelaku tersebut dapat menyesuaikan tingkah laku dengan kesadarannya yang mana diperbolehkan atau tidak. ${ }^{22}$

\footnotetext{
1959).[202].

${ }^{9}$ Alf Ross, On Law and Justice (Univercity of California Press, Berkeley \& Los Angeles

${ }^{20}$ Moeljatno, Asas-asas Hukum Pidana (Bina Aksara 1987).[155].

${ }_{21}^{21}$ Moeljatno, Asas-asas Hukum Pidana (Rinekacipta 2000).[165].

22 ibid.[166].
} 
Jadi pelaku yang melakukan tindak pidana meskipun terbukti secara sah dan meyakinkan melakukan tindak pidana, tidak akan dipidana, karena jiwanya cacat dalam pertumbuhan, atau terganggunya karena suatu penyakit. Hal ini berarti bahwa seseorang dapat dimintakan pertanggungjawaban atas perbuatannya tersebut jika:

a. Kemampuan berpikir pembuat yang memungkinkan ia menguasai pikirannya, yang memungkinkan ia menentukan perbuatannya;

b. Dan oleh sebab itu, ia dapat memahami makna dan akibat perbuatannya;

c. Dan oleh sebab itu pula, ia dapat menentukan kehendak sesuai dengan pendapatnya. ${ }^{23}$

Terhadap pelaku tindak pidana yang karena jiwanya cacat dalam pertumbuhan atau terganggu karena suatu penyakit, hakim yang memeriksa dapat memintakan dalam putusannya supaya pelaku dimasukkan ke rumah sakit jiwa.

Sudarto menjelaskan bahwa, agar seseorang tersebut memiliki aspek pertanggungjawaban pidana, dalam arti dipidananya pembuat, terdapat beberapa syarat yang harus dipenuhi, yaitu:

1. Adanya suatu tindak pidana yang dilakukan oleh pembuat;

2. Adanya unsur kesalahan berupa kesengajaan atau kealpaan;

3. Adanya pembuat yang mampu bertanggungjawab;

4. Tidak ada alasan pemaaf. ${ }^{24}$

Mengenai kedudukan sebagai pembuat dan sifat pertanggungjawaban pidana korporasi, terdapat model pertanggungjawaban korporasi sebagai berikut:

a. Pengurus korporasi sebagai pembuat dan penguruslah yang bertanggungjawab;

b. Korporasi sebagai pembuat dan pengurus bertanggungjawab; dan

c. Korporasi sebagai pembuat dan juga sebagai yang bertanggungjawab. ${ }^{25}$

Pertanggungjawaban pidana yang ada di dalam korporasi tidak boleh dibebankan dengan menggunakan pasal yang diatur dalam KUHP karena antara tindak pidana yang dilakukan oleh manusia dengan tindak pidana yang dilakukan korporasi memiliki karakteristik yang berbeda. ${ }^{26}$

${ }^{23}$ Andi Hamzah, Asas-asas Hukum Pidana Bagian Pertama (Alumni 1997).

${ }^{24}$ Sudarto, Hukum dan Hukum Pidana (Alumni 1986).[77].

25 Muladi dan Dwidja Priyatno, Pertanggungjawaban Pidana Korporasi (Prenada Media Group 2010).[83].

${ }^{26}$ Mahrus Ali, Asas-asas Hukum Pidana Korporasi (Rajawali Pers 2013).[177]. 


\section{Pelaku Tindak Pidana Melalui Pinjaman Online}

Jika membahas tentang pertanggungjawaban pidana, maka hal tersebut tidak akan pernah lepas dari asas pertanggungjawaban pidana yaitu "keine strafe ohne schuld atau geen straf zonder schuld atau nulla poena sine culpa atau actus non facit reum nisi mens rea". ${ }^{27}$ Yang jika diartikan ke dalam bahasa Indonesia sama dengan "tiada pidana tanpa kesalahan" mengenai penyertaan dan pembantuan dalam tindak pidana. ${ }^{28}$

Menurut KUHP subjek Hukum Pidana adalah perseorangan,karena di dalam KUHP tidak ada yang dapat menjerat tentang korporasi (badan hukum yang melakukan tindak pidana). Hal tersebut dapat dilihat ke dalam Pasal 59 KUHP yang menjelaskan bahwa subjek hukum adalah manusia alamiah yang dapat melakukan suatu tindak pidana. Menurut moeljatno, berikut adalah bunyi Pasal 59 KUHP, yaitu:

"Dalam hal-hal dimana karena pelanggaran ditentukan pidana terhadap pengurus anggota-anggota badan pengurus atau komisaris-komisaris, maka pengurus, anggota badan pengurus atau komisaris yang ternyata tidak ikut campur melakukan pelanggaran tidak dipidana".

Menurut ketentuan pasal di atas, penjabaran dari pengurus anggota-anggota badan pengurus atau komisaris dapat diibaratkan dengan pimpinan dan para anggota serta yang lain. Sedangkan pandangan KUHP bahwa subjek hukum adalah manusia alamiah yang semata-mata yang bisa menjadi subjek hukum pidana tersebut, adanya pemikiran yang didasari bahwa hanya manusia saja yang mempunyai mens rea an makhluk hidup lain maupun korporasi, yaitu badan yang diciptakan manusia melalui hukum, yang dianggap tidak mempunyai mens rea. ${ }^{29}$

R. Soesilo dalam bukunya menjelaskan mengenai yang dimaksud dengan "orang yang turut melakukan" dalam Pasal 55 KUHP dalam arti kata "bersamasama melakukan”. Sedikit-dikitnya harus ada dua orang, ialah orang yang melakukan (pleger) dan orang yang turut melakukan (medepleger) peristiwa

\footnotetext{
${ }^{27}$ Moeljatno, Asas-asas Hukum Pidana (Rineka Cipta 199).[153].

28 ibid.[164].

29 Edi Yunara, Korupsi dan Pertanggungjawaban Pidana Korporasi, Berikut Studi Kasus, (Citra Aditya Bakti 2005).[28].
} 
pidana. Dijelaskan bahwa kedua orang itu semuanya melakukan perbuatan yang sama dalam pelaksanaan peristiwa tindak pidana itu. Sedangkan mengenai Pasal 56 KUHP, R. Soesilo menjelaskan bahwa orang “membantu melakukan” jika ia sengaja memberikan bantuan tersebut, pada waktu atau sebelum (jadi tidak sesudahnya) kejahatan itu dilakukan. Dalam penjelasan Pasal 56 KUHP ini dikatakan bahwa harus terdapat elemen "sengaja", sehingga orang yang kebetulan tidak mengetahui telah memberikan kesempatan, daya upaya, atau keterangan untuk melakukan kejahatan itu tidak dihukum. Adanya "niat" untuk melakukan kejahatan itu harus timbul dari orang yang telah diberi bantuan, kesempatan, daya upaya atau keterangan itu.

\section{Sanksi Pidana Terhadap Pelaku tindak Pidana Pinjaman Online}

Suatu sanksi pidana (punishment), dapat didefinikasikan sebagai suatu nestapa atau penderitaan yang ditimpakan kepada orang yang telah melakukan perbuatan yang dilarang oleh hukum pidana. ${ }^{30}$ Pertanggungjawaban bagi debitur yang gagal dalam melunasi hutangnya adalah pihak debitur tetap harus melunasi hutangnya karena sudah melakukan perjanjian dan telah menerima uang pinjaman tersebut. Namun, jika pihak debitur tidak ada itikad baik maka dapat dikenakan Pasal 378 KUHP tentang Penipuan karena telah melanggar perjanjian yang ada dan dapat diancam dengan pidana penjara paling lama 4(empat) tahun.

Ancaman pidana bagi yang menghimpun dana tanpa ijin sangatlah berat, selain itu juga, tidak ada pengganti hukuman denda uang apabila denda tidak dapat dipenuhi (subside) tidak ada dalam undang-undang tersebut yang menunjukkan betapa beratnya sanksi hukuman tersebut. Maraknya kasus dibidang pinjaman online berkedok investasi banyak sekali merugikan masyarakat. Istilah tersebut lebih dikenal dengan menghimpun dana. Para pelaku kejahatan yang menghimpun dana tersebut meminjamkan uang dengan syarat yang mudah dan memberikan bunga yang sangat besar sehingga para kreditur dapat mendapatkan keuntungan dengan hasil bunga tersebut.

\footnotetext{
${ }^{30}$ Mahrus Ali, Op.Cit.[251].
} 
Pinjaman uang yang mudah dan cepat tanpa syarat tersebut muncul untuk mengelabuhi masyarakat hingga kasus pembunuhan diri yang ada. Namun, suku bunga yang bertambah tinggi di setiap harinya dan sering pelaku penghimpun dana masyarakat merayu melalui iklan ataupun mengirim SMS kepada para nasabah.

Dalam hal penipuan yang dilakukan oleh debitur (peminjam) maka dapat dikenakan Pasal 378 KUHP maka diancam dengan pidana penjara paling lama 4(empat) tahun. Dalam investor yang melakukan tindak pidana pemerasan dan dapat dijerat Pasal 368 KUHP maka diancam dengan pidana penjara paling lama 9 (Sembilan) tahun dan terkait pengancaman dengan Pasal 369 KUHP maka diancam dengan pidana penjara paling lama 4 (empat) tahun. Sedangkan di dalam UU ITE, mengenai sanksi terhadap pelaku penipuan tidak diatur secara khusus mengenai tindak pidana penipuan. Selama ini, tindak pidana penipuan hanya diatur di dalam Pasal 378 KUHP yang dapat diancam dengan penjara paling lama 4 (empat) tahun. Walaupun UU ITE tidak khusus mengatur mengenai tindak pidana penipuan, namun terkait dengan kerugian konsumen yang ditimbulkan dalam transaksi.

Dalam UU ITE, mengenai sanksi terhadap pelaku yang melakukan tindak pidana pemerasan dan tindak pidana pengancaman yang dilakukan melalui media online diatur dalam Pasal 29 UU ITE yang berbunyi "Setiap Orang dengan sengaja dan tanpa hak mengirim Informasi Elektronik dan/atau Dokumen Elektronik yang berisi ancaman kekerasan atau menkut-nakuti yang ditunjukkan secara pribadi”.

Sesuai dengan pengaturan Pasal 45 ayat (3), terhadap pelanggaran Pasal 29 UU ITE diancam pidana penjara paling lama 12 (dua belas) tahun dan/atau denda 2 (dua) Milyar rupiah. Jadi, melalui rumusan-rumusan Pasal 368 dan Pasal 369 KUHP jika dibandingkan dengan Pasal 29 UU ITE kita dapat mengetahui bahwa kedua aturan tersebut mengatur tentang hal yang berbeda. Pasal 368 dan Pasal 369 KUHP mengatur tentang pemerasan dan pengancaman, sementara Pasal 29 UU ITE mengatur mengenai pemerasan dan pengancaman melalui media internet atau media elektronik lainnya yang pelaku kejahatannya mengancam baik seksual atau keamanan terhadap orang lain sehingga menimbulkan ketakutan para korban. 
Pada akhirnya, sangat dibutuhkan kejelian pihak penyidik kepolisian untuk menentukan kapan harus menggunakan Pasal 368 KUHP dan kapan juga harus menggunakan ketentuan-ketentuan dalam Pasal 29 UU ITE. Namun jika pada praktinya, pihak kepolisian dapat menjerat dengan pasal berlapis jika tindak pidana tersebut memenuhi unsur-unsur tindak pidana Pemerasan dan pengancaman sebagaimana diatur di Pasal 368 dan Pasal 369 KUHP dan memenuhi unsurunsur di Pasal 29 UU ITE. Maka unsur-unsur tersebut terpenuhi dan polisi dapat menggunakan pasal tersebut.

UU ITE terkait Pasal 29 jo. Pasal 45 ayat (3) dapat membantu kekurangan yang ada di dalam KUHP walaupun UU ITE tersebut tidak secara khusus mengatur ketentuan tentang kejahatan pemerasan dan pengancaman, namun pasal tersebut dapat digunakan untuk memberikan sanksi kepada pelaku dalam mempertanggungjawabkan perbuatan kejahatannya. Pelaku dalam tindak pidana pinjaman online ini adalah korporasi, namun di dalam korporasi tidak hanya badan hukum atau legal person tetapi juga orang (manusia) atau natural person. Karena dalam pinjaman online banyak yang mendirikan usahanya yang berbentuk badan hukum dan orang (natural person).

\section{Kesimpulan}

Pinjaman online sebenarnya hampir sama dengan pinjaman secara konvensional, hanya saja debitur dan kreditur tidak saling bertemu, bertatap muka, dan transaksi yang dilakukan melalui media online yang disebut transaksi elektronik. Timbulnya berbagai macam tindak pidana dalam pinjaman online, dikarenakan adanya motif dari seseorang yang ingin mendapatkan keuntungan dengan cara-cara melawan hukum, karena menggunakan kesempatan tidak bertemunya antara pihak debitur dan kreditur. Ketentuan yang dapat dikenakan adalah Pasal 378 tentang penipuan, Pasal 368 dan Pasal 369 KUHP tentang pemerasan dan pengancaman, Pasal 29 jo. Pasal 45 ayat (3) UU ITE.

Pertanggungjawaban pidana melalui pinjaman online bagi pihak debitur yang gagal dalam membayar maka tetap harus melunasi hutangnya dan jika tidak ada 
itikad baik maka dijerat Pasal 378 KUHP, dan bagi kreditur dapat dikenakan Pasal 368 KUHP dan Pasal 369 KUHP tentang pemerasan dan pengancaman, Pasal 29 jo. Pasal 45 ayat (3) UU ITE. Tidak hanya melibatkan pelaku orang-perseorangan tetapi juga korporasi. Meskipun korporasi merupakan subyek hukum, tetapi pemidanaannya tetap dikenakan perseorangan atau ditujukan langsung kepada pelaku yang melanggar hukum tersebut.

\section{Daftar Bacaan}

\section{Buku}

Ali, Mahrus, Asas-asas Hukum Pidana Korporasi (Rajawali Pers 2013).

Andi Hamzah, Delik-Delik Tertentu (Speciale Delicten) Di Dalam KUHP (Sinar Grafika 2009).

Andi Hamzah, Asas-asas Hukum Pidana (Bagian Pertama, Alumni 1997).

Huda, Chairul, Dari Tiada Pidana Tanpa Kesalahan' Menuju Kepada “Tiada Pertanggungjawaban Pidana Tanpa Kesalahan (Prenada Media 2006).

Makarim, Edmon, Kompilasi Hukum Telematika (Raja Grafindo Persada 2004).

Maskun, Kejahatan Siber (Cyber Crime) (Prenada Media Group 2013).

Mihardja, A.K, Polemik Kebudayaan (Balai Pustaka 1998).

Moeljatno, Asas-asas Hukum Pidana (Rinekacipta 2008).

Poernomo, Bambang, Asas-asas Hukum Pidana (Ghalia Indonesia 1992).

Prodjodikoro, Wirjono, Tindak-Tindak Pidana Tertentu Di Indonesia (PT. Refika Aditama 2003).

Priyatno, Dwidja dan Muladi, Pertanggungjawaban Pidana Korporasi (Prenada Media Group 2010).

Sudarto, Hukum dan Hukum Pidana (Alumni 1986).

Yahman, Karakteristik Wanprestasi \& Tindak Pidana Penipuan (PT. Prestasi Prestasi Pustakaraya 2011). 
Yunara, Edi, Korupsi dan Pertanggungjawaban Pidana Korporasi, (Berikut Studi Kasus, Citra Aditya Bakti 2005).

\section{Perundang-undangan}

Undang-Undang Nomor 1 Tahun 1946 tentang Peraturan hukum Pidana.

Undang-Undang Nomor 8 Tahun 1981 tentang Hukum Acara Pidana.

Undang-Undang 11 Tahun 2008 tentang Informasi dan Transaksi Elektronik.

Undang Undang Nomor 13 Tahun 2006 Perlindungan Saksi dan Korban.

Undang-Undang Nomor 19 Tahun 2016 tentang Perubahan Atas Undang-Undang 11 tahun 2008 tentang Informasi dan Transaksi Elektronik.

Undang-Undang Nomor 8 Tahun 1999 tentang Perlindungan Konsumen.

Peraturan Pemerintah Nomor 82 Tahun 2012 tentang Penyelenggaraan Sistem dan Transaksi Elektronik.

Peraturan Menteri Nomor 20 Tahun 2016 tentang Perlindungan Data Pribadi Sistem Elektronik.

Peraturan Otoritas Jasa Keuangan Nomor 77//PJOK.01/2016 Tahun 2016 tentang Layanan Pinjam Uang Berbasis Teknologi Informasi.

Peraturan Bank Indonesia Nomor 19/12/PBI/2017 tentang Penyeleng-garaan Teknologi Finansial. 